\title{
INDUCCIÓN DE MUERTE CELULAR EN LAS INFECCIONES INTRAMAMARIAS
}

\author{
DALLARD, B. $E^{1}$
}

\begin{abstract}
RESUMEN
La mastitis es una reacción inflamatoria de la glándula mamaria causada normalmente por infección microbiana y está reconocida como la enfermedad más costosa del ganado lechero. El daño en el tejido mamario puede estar inducido por dos mecanismos principales, necrosis o apoptosis. Estas dos formas de muerte de las células pueden ser distinguidas por cambios morfológicos, bioquímicos y moleculares en las células agonizantes. Tanto los factores bacterianos como las reacciones inmunes del hospedador contribuyen al daño del tejido epitelial. La mastitis se caracteriza por un influjo de células somáticas, principalmente neutrófilos polimorfonucleares (PMNs), dentro de la glándula mamaria. La migración de células inmunes, la ruptura de la barrera sangre-leche y el daño en la membrana basal conducen a la muerte de la célula epitelial. El esclarecimiento de los cambios bioquímicos y celulares que ocurren en la glándula durante la mastitis permitirá proponer medidas para manipular las funciones mamarias a los efectos de minimizar el daño en el tejido.

Palabras clave: bovino, glándula mamaria, mastitis, apoptosis, daño tisular.
\end{abstract}

\section{SUMMARY}

\section{Cellular death induction in mammary infections.}

Mastitis is an inflammatory reaction of the mammary gland that is usually due to a microbial infection and is recognized as the most costly disease in dairy cattle. The mammary tissue damage has been shown to be induced by either apoptosis or necrosis. These two distinct types of cell death can be distinguished by morphological, biochemical and molecular changes in dying cells. Both bacterial factors and host immune reactions contribute to epithelial tissue damage. Mastitis is characterized by an influx of somatic cells, primarily polymorphonuclear neutrophils (PMNs), into the mammary gland. The immune cells migrating into the mammary gland, breakdown of the blood-milk barrier and damage of the extracellular matrix can lead to death of epithelial cells. Understanding the biochemical and cellular changes that occur in the gland during mastitis will ultimately lead to means of manipulating mammary functions to minimize the damage from mastitis.

Key words: bovine, mammary gland, mastitis, apoptosis, tissue damage.

1.- Cátedra de Histología y Embriología. Facultad de Ciencias Veterinarias, Universidad Nacional del Litoral. Kreder 2805. (3080) Esperanza, provincia de Santa Fe. Email: bdallard@fcv.unl.edu.ar Manuscrito recibido el 17 de octubre de 2007 y aceptado para su publicación el 21 de noviembre de 2007. 